aims to present the relevant role of Clark's response to the problem of evil.

Keywords: problem of evil, theodicy, free will, predestination, Christianity

\section{TEODICEIA CALVINISTA: A RESPOSTA DE GORDON CLARK AO PROBLEMA DO MAL ${ }^{1}$}

\author{
Felipe Sabino de Araújo Neto \\ Mestre em Filosofia UnB \\ Mestrando Mackenzie
}

\begin{abstract}
Resumo: Entende-se por teodiceia a tentativa de justificar Deus, tanto a sua existência como seus atributos (sobretudo bondade e onipotência), diante dos males presentes no mundo. Gordon Clark (1902-1985) foi um teólogo e filósofo cristão que, por meio dos seus escritos, abordou os principais temas e problemas enfrentados pela filosofia e religião. Embora um herdeiro da tradição reformada, sua proposta diverge consideravelmente daquela apresentada pelo famoso filósofo da religião Alvin Plantinga. Neste contexto, este artigo pretende apresentar o papel relevante da resposta de Clark ao problema do mal.
\end{abstract}

Palavras-chave: problema do mal, teodiceia, livre arbítrio, predestinação, cristianismo

\begin{abstract}
Theodicy is the attempt to justify God, his existence and his attributes (mainly his goodness and his omnipotence), in view of the existence of evil in the world. Gordon Clark (1902-1985) was a Christian theologian and philosopher who through his writings addressed the main issues and problems faced by philosophy and religion. Although a heritor from the Reformed tradition, his proposal diverges considerably from that presented by the famous philosopher of religion Alvin Plantinga. In this context, the present study
\end{abstract}

\section{INTRODUÇÃO}

O chamado problema do mal tem sido um assunto recorrente em debates filosóficos e teológicos há séculos. A despeito da antiguidade do problema, as controvérsias ao redor do tema parecem não ter fim. Por um lado, ateus e inimigos da religião utilizam o problema do mal para provar a inexistência de Deus, ou ao menos demonstrar a pequena probabilidade dele existir. Por outro, teístas ao longo dos anos têm lutado para entender as "coisas terríveis" que acometem todos os seres humanos, inclusive os que professam a fé em Deus. Não obstante crerem em Deus, não poucos se veem incapazes de conciliar a sua fé num Deus bondoso e poderoso com a experiência do mal.

Embora o problema do mal, como "arma" contra a existência de Deus, seja direcionado contra os teístas em geral, os cristãos são um alvo predileto. O motivo ficará evidente ao enunciar exatamente no que consiste $o$ problema do mal.

O que, então, é o problema do mal? Trata-se da suposta incompatibilidade entre a existência de Deus e a ocorrência de mal em nosso mundo. O problema foi levantado por Epicuro, filósofo grego, que viveu no século IV antes de Cristo. Embora não seja recente, a declaração tornouse clássica com o filósofo britânico David Hume (1711-1776), que repete o mesmo argumento em seus Diálogos sobre a Religião Natural. Diz-nos o famoso cético:
A Divindade quer evitar o mal, mas não é capaz? Então ela é impotente. Ela é capaz, mas não quer evitá-lo? Então ela é malévola. Ela é capaz de evitá-lo e quer evitá-lo? De onde, então, provém o mal? (HUME, 1992, p. 136)

\footnotetext{
${ }^{1}$ Este artigo já foi publicado também na forma de capítulo de livro.
} 
O cerne do argumento pode ser posto na forma de um silogismo bem simples:

1. Se Deus existe, ele quer e pode acabar com o mal no mundo.

2. Existe mal no mundo.

3. Logo, Deus não existe.

Desde então, esse e formas similares desse silogismo têm sido usados contra a crença teísta. Embora, como dissemos anteriormente, a questão do mal seja problemática para todos os teístas, o cristão se encontra numa situação peculiar. O motivo é que, teoricamente, um teísta não-cristão pode alegar crer em um deus que não seja onipotente, ou que não seja bondoso. Ou seja, o deus dessa pessoa pode ser incapaz de acabar com o mal, ou não desejar acabar com o mal, ou ambas as coisas. Mas não é assim com o cristão. Não somente os teólogos da tradição cristã têm afirmado a onipotência e a suprema bondade de Deus, como também a Escritura Sagrada cristã apresenta tais coisas como atributos imutáveis de Deus. O filósofo Derk Pereboom reconhece isso quando afirma:

\begin{abstract}
Virtualmente todas as religiões monoteístas professam que há um ser divino que é significantemente bom, conhecedor e poderoso. Os males deste mundo apresentam vários desafios para tais religiões. O desafio mais forte é direcionado contra visões de acordo com as quais há um ser que é totalmente bom, onisciente e onipotente. (PEREBROM, 2005, p. 148)
\end{abstract}

Com efeito, este artigo visa analisar a solução ao problema do mal proposta pelo filósofo e teólogo reformado Gordon Clark.

\section{QUEM FOI GORDON CLARK?}

Gordon Haddon Clark nasceu em 31 de agosto de 1902, na Filadélfia. Após se graduar na Universidade da Pensilvânia em 1924, terminando um bacharelado em francês, Clark começou seus estudos de pós-graduação em filosofia na mesma universidade. Durante seus anos como estudante de pós-graduação, começou a ensinar filosofia, uma carreira que continuou na Universidade da Pensilvânia até 1936. Clark recebeu seu Ph.D. em 1929, tendo escrito uma dissertação intitulada "Empedocles and Anaxagoras in Aristotle's $D e$ Anima" (CRAMPTON, 1999).

É interessante que, apesar de ser um ministro ordenado pela Igreja Presbiteriana, e ter ajudado a organizar outra denominação, tendo assim uma vida eclesiástica ativa, a maioria das publicações de Clark antes de 1952 foram artigos em jornais ou livros seculares de filosofia publicados por editoras seculares. $\mathrm{O}$ primeiro livro de Clark, Readings in Ethics, foi publicado em 1931. Editado em colaboração com Thomas V. Smith, da Universidade de Chicago, o livro tornou-se um texto usado amplamente e passou por diversas edições. Selections from Hellenistic Philosophy e A History of Philosophy foram publicados em 1940 e 1941, respectivamente. Embora Clark tenha publicado uns poucos artigos para revistas evangélicas como Moody Monthly e outros periódicos teologicamente mais sérios, como o Evangelical Quarterly e o Westminster Theological Journal, a maior parte dos seus artigos e resenhas publicadas antes de 1952 apareceram em jornais acadêmicos tais como New Scholasticism e Philosophical Review. Como lembra Ronald Nash, "esses estudos refletem seu contínuo interesse em filosofia antiga, especialmente o pensamento de Plotino" (NASH, 1996, p. 271). 
Antes de analisar a resposta de Gordon Clark ao problema do mal, precisamos ponderar sobre o papel da teologia na filosofia, particularmente na obra do filósofo Richard Swinburne.

\section{TEOLOGIA A SERVIÇO DA FILOSOFIA}

Em anos recentes houve uma nova mudança na abordagem filosófica do problema do mal. Não foi algo tão radical como o relativo abandono do argumento dedutivo em favor do argumento indiciário, ${ }^{2}$ mas é digno de menção. A mudança consiste na introdução de elementos teológicos no tratamento filosófico do problema do mal. Embora, de forma alguma, uma abordagem limitada a eles, os filósofos Richard Swinburne e Marilyn Adams constituem dois exemplos importantes do uso da teologia para explicar filosoficamente a existência do mal no mundo de um Deus bom e onipotente. Infelizmente, o espaço não permite que analisemos as obras de ambos os filósofos, de forma que nos restringiremos a Swinburne.

Richard Swinburne é um renomado filósofo cristão. Além de professor de filosofia da religião cristã na Universidade de Oxford de 1985 a 2002, ano de sua aposentadoria, Swinburne publicou inúmeros livros sobre filosofia e cristianismo. Entre eles, merecem destaque Providence and the Problem of Evil, The Coherence of Theism, The Existence of God e Faith and Reason. Embora Swinburne tenha tratado com a questão do problema do mal em inúmeros artigos e palestras, bem como em partes do livro The Existence of God, ${ }^{3}$ a sua resposta mais elaborada e completa é apresentada no livro Providence and the Problem of Evil. Neste livro Swinburne responde à antiga pergunta: por que um Deus amoroso permite que os seres humanos sofram tanto? Logo na introdução Swinburne (SWINBURNE, 1998, p. x) nos lembra que a onipotência divina não significa que Deus pode fazer qualquer coisa. Antes, Deus pode fazer qualquer coisa logicamente possível, isto é, algo cuja descrição não envolva uma contradição. Assim, a onipotência divina não significa que Deus pode fazer um triângulo quadrado, nem tornar verdadeira a equação $2+2=5$.

Ao longo de todo o livro Swinburne utiliza a teologia cristã, isto é, outras doutrinas cristãs além da existência de Deus, para responder aos dilemas envolvidos na existência do mal. Tais doutrinas são fundamentais para substanciar as suas propostas. É interessante que Swinburne não apresenta argumentos positivos em favor da veracidade dessas outras doutrinas cristãs. Pelo contrário, ele afirma de forma ousada que "o argumento positivo deve vir em grande parte da revelação" (1998, p. xi). Em outras palavras, ele pressupõe a veracidade dessas doutrinas e trabalha em cima dessa pressuposição. O seu desembaraço em usar a teologia para lidar com um assunto altamente filósofo é tão grande que ele começa cada um

\footnotetext{
2 Existe um indício de que Deus não existe? O argumento indiciário (evidencial) do mal, diferente do argumento dedutivo, resposta de forma mais modesta a esse questionamento. Em vez de afirmar ser impossível que Deus e o mal coexistam, o argumento do tipo indiciário tenta estabelecer que certos males que ocorrem no mundo tornam a existência de Deus improvável. Em termos gerais, argumentos dessa natureza tentam estabelecer que os males do mundo reduzem a probabilidade da existência de Deus a ponto de ficar abaixo de um grau de verdade em que seria justificado acreditar.

3 Disponível em português sob o título A existência de Deus (Brasília: Academia Monergista, 2015). Veja também, do mesmo autor, Deus existe? (Brasília: Academia Monergista, 2015).
} 
dos treze capítulos do livro com extensas citações da Bíblia, de Gênesis a Apocalipse.

Em The Existence of God (2004) Swinburne apresenta as doutrinas da vida eterna e da expiação como hipóteses auxiliares à hipótese do teísmo. Contudo, aqui o seu objetivo não é responder ao problema da ocorrência do mal, mas sim à intensidade e quantidade desses males.

O ponto crucial do problema do mal, de acordo com Swinburne (2004, p. 263), não é a ocorrência do mal, nem os tipos de males. Antes, é a quantidade de pessoas (e animais) que sofrem, bem como o quanto elas sofrem.

Considerando isso, Swinburne (2004, pp. 264-65) apresenta a doutrina da expiação como uma das forças do teísmo cristão em sua resposta ao problema do mal. Por causa da sua bondade, Deus se encarnou, habitou entre nós e compartilhou do nosso sofrimento. É justamente isso o que esperaríamos de um Deus bondoso, continua Swinburne. É algo similar aos pais que, a despeito de não estarem doentes, partilham da mesma dieta restrita à qual os seus filhos estão submetidos por questões de saúde.

Mas para Swinburne (2004, p. 265) Deus só estaria justificado em permitir o mal caso se, além de se encarnar e partilhar do nosso sofrimento, ele providenciasse um período compensatório de vida boa após a morte.
Swinburne (2004, p. 266) admite que a pluralidade e a intensidade do mal constituem um bom argumento indutivo contra a existência de Deus, isto é, contra o teísmo em geral. Contudo, não contra o teísmo cristão, que postula a existência de Deus juntamente com outras doutrinas. A doutrina da vida após a morte está entre esses ensinos que diminuem a força do argumento indutivo contra a existência divina. Afinal, no sistema cristão, a vida pós-morte não tem o intuito apenas de recompensar os virtuosos, mas também de compensar o sofrimento. A famosa parábola do rico e de Lázaro, proferida por Jesus e registrada no Evangelho segundo São Lucas é um exemplo disso. Swinburne (2004, p. 266n) lembra-nos que a boa vida de Lázaro após a morte é apresentada claramente como uma compensação pelo seu sofrimento durante sua peregrinação na terra. Assim, por mais que os sofrimentos sejam excruciantes nesta vida, eles não podem ser comparados com a quantidade e intensidade de bem na vida futura. Esta vida, além de passageira, está repleta de coisas boas; a vida futura, além de eterna, ${ }^{4}$ está ausente de coisas ruins. O argumento de Swinburne poderia muito bem ser considerado um desenrolar da afirmação do apóstolo Paulo em Romanos 8.18: "Porque para mim tenho por certo que os sofrimentos do tempo presente não podem ser comparados com a glória a ser revelada em nós".

\footnotetext{
${ }^{4}$ No cristianismo, a vida eterna já começa nesta vida. Contudo, os cristãos não desfrutam agora de todas as bênçãos que lhes estão reservadas. Em outras palavras, existe um elemento de já e ainda não na escatologia cristã. A ênfase de Swinburne é no aspecto "temporal” dessa vida futura: diferente da vida neste mundo, ela é eterna, ou seja, não tem fim.
} 
Tendo considerado o papel da teologia em propostas filosóficas contemporâneas, estamos prontos para considerar, na próxima seção, as contribuições do filósofo e teólogo cristão Gordon Clark. Em Clark, veremos de maneira ainda mais notória o auxílio que a teologia pode prestar à filosofia no que diz respeito ao problema do mal, isto é, na construção de uma teodiceia. $^{5}$

\section{A RESPOSTA DE GORDON CLARK AO PROBLEMA DO MAL}

O problema do mal, como sugere o professor Sérgio Miranda (2013, posição 37), é um problema filosófico autêntico. Ou seja, ele pode receber algumas respostas mais plausíveis do que outras, mas nunca uma resposta definitiva. Isso significa que o problema do mal, enquanto um problema filosófico autêntico, é um problema tão importante e atual para nós quanto o foi para Epicuro, Agostinho, Leibniz e David Hume. Sendo assim, Gordon Clark, como filósofo e teólogo cristão, não deixou de abordar o assunto. De fato, ele tinha motivos sobejos para lidar com a questão, posto que sempre tentou, em oposição veemente ao irracionalismo defendido em nome do cristianismo, apresentar e defender o teísmo cristão como uma crença racional.

Gordon Clark (2011, p. 91) reconhece que o problema do mal, isto é, calamidades físicas como terremotos e tragédias causadas por homens perversos, têm levado alguns filósofos a negar completamente a existência de Deus, ou a pelo menos defender um deus finito. Dessa forma, interessado em defender $o$ cristianismo contra a acusação de crença irracional, Clark abordou o problema do mal em vários dos seus muitos escritos.

O objetivo desta seção é apresentar a proposta de Clark ao problema do mal. De maneira similar a filósofos como Richard Swinburne e Marilyn Adams, Clark faz extenso uso da teologia cristã para enfrentar o problema filosófico do mal. Contudo, diferente destes, a sua proposta tem como arcabouço teológico a teologia reformada ou calvinista. Ao avaliar a resposta direta de Clark ao problema do mal, faremos isso abordando algumas das peculiaridades de sua proposta.

\subsection{Livre-arbítrio e livre agência}

Desde Agostinho, teólogos e filósofos cristãos têm procurado a solução para o problema do mal no livre-arbítrio humano. Embora haja diferenças significativas entre as soluções apresentadas ao longo da história do cristianismo, algumas sendo mais complexas que outras, todas compartilham a ideia de que a liberdade do homem isenta Deus de culpa pela presença do mal no mundo. $\mathrm{O}$ mal existe no mundo pelo mau uso que o homem fez e faz do seu livre-arbítrio. Com certeza Deus poderia criar os homens sem livre-arbítrio e impedir assim que eles agissem perversamente. Contudo, assim segue o argumento, é melhor o mal num mundo onde haja livre-arbítrio, do que a inexistência do livre-arbítrio como "pagamento" pela ausência do mal. Em outras

\footnotetext{
${ }^{5}$ Embora incomum no linguajar popular, teodiceia é um termo muito usado e conhecido na filosofia, em especial na filosofia da religião. O termo foi cunhado pelo filósofo alemão G.W. Leibniz (1646-1716), sendo etimologicamente derivado das palavras gregas theos (deus) e dike (justiça). A palavra significaria, então, algo como "a justificação de Deus". Ou seja, é a tentativa de justificar, vindicar ou defender a bondade e onipotência de Deus em vista da presença do mal no mundo.
} 
palavras, o livre-arbítrio é algo tão precioso que justificaria a presença do mal.

Todavia, tornou-se lugar comum entre seguidores da teologia reformada negar $\mathrm{o}$ conceito popular de livre-arbítrio. A negação surgiu primariamente nos debates acerca da doutrina da salvação (soteriologia) com os chamados arminianos (seguidores teológicos de Tiago Armínio) e católico-romanos. Ao negar o livre-arbítrio, os teólogos reformados estavam mais interessados em negar que o homem possuía liberdade para deixar de pecar, liberdade para obedecer à lei de Deus e liberdade para agir contrariamente aos decretos de Deus. Mas embora tal negação tenha importância primária nas discussões soteriológicas, ela tem implicações inevitáveis para o problema do mal. Afinal, se o homem não tem livre-arbítrio, não se pode recorrer mais a este numa teodiceia.

Ao descartar o conceito e nomenclatura do livre-arbítrio, por vezes os teólogos reformados definiram a sua visão sobre liberdade como livre agência. Por livre agência eles desejam enfatizar que o homem é um agente moral livre cuja liberdade consiste em agir de acordo com a sua própria natureza, isto é, em conformidade com os seus desejos e inclinações. Dessa forma, embora o homem seja livre de forças externas (ou leis psicoquímicas), ele não é livre de si mesmo, muito menos de Deus. Tendo uma visão considerada por muitos como extremada sobre a depravação humana, ao afirmar que o homem não poderia agir contra a sua natureza, os reformados negavam que o ser humano possuísse liberdade para não pecar e liberdade para cumprir a lei de Deus, negando por consequência a salvação pelas obras.

Essa é exatamente a posição de Gordon Clark. Para ele, a vontade humana não é determinada por fatores físicos ou psicológicos. O homem não é uma máquina; dessa forma, seus movimentos (ações, escolhas, planos, etc.) não podem ser descritos mediante equações matemáticas, como fazemos para descrever os movimentos dos planetas. A vontade do homem não é determinada por qualquer necessidade absoluta da natureza (CLARK, 2001, p. 106). Contudo, visto que existem fatores determinantes que agem na vontade humana, incluindo Deus, não podemos dizer que o homem possui livre-arbítrio. Livrearbítrio seria a ideia de que duas escolhas incompatíveis são igualmente possíveis de serem escolhidas por uma pessoa. Por outro lado, livre agência traduziria a ideia de que todas as escolhas são inevitáveis. A liberdade que a vontade humana possui é liberdade da compulsão ou da coação, mas não liberdade da ação e poder de Deus (CLARK, 1995, p. 228).

Embora o homem faça suas escolhas, Clark (2001, p. 108) afirma que todas essas escolhas são determinadas por Deus. Fazendo uma exegese de Êxodo 34.24, Clark conclui que até mesmo os desejos dos pagãos são controlados por Deus. Em 2 Samuel 17.14, o ensino seria que Deus predestinou não apenas os eventos visíveis e externos, mas as decisões e escolhas dos homens também.

As decisões e as escolhas são predestinadas, mas Deus não faz violência à vontade de suas criaturas. Não é o caso de João desejar seguir um plano $X$, e ser então forçado a seguir o plano Y contra os seus desejos. Os processos psicológicos de João produziram o desejo de seguir o plano X. Embora, é claro, Deus estabeleça os processos psicológicos tanto quanto os físicos.

É digno de nota que a Escritura cristã, a Bíblia, é repleta de profecias, isto é, predições de Deus 
acerca do futuro. Por exemplo, diversas passagens bíblicas haviam predito que $o$ Messias seria traído e crucificado por anunciar a vontade de Deus. Contudo, se Deus não controlasse todas as suas criaturas, incluindo suas decisões, ele não poderia garantir o cumprimento de suas próprias profecias. Judas poderia não ter vendido Cristo por trinta moedas de prata, e Cristo poderia não ter sido crucificado ao lado de malfeitores. Dessa forma, conclui Clark (2001, p. 108), um cristão nunca deveria construir uma teoria de liberdade humana que negasse a onipotência e a graça de Deus.

Para aqueles que não ficam confortáveis com a ideia de não termos livre-arbítrio, Clark lança um desafio. $\mathrm{O}$ cristianismo sempre anunciou a vida após morte, onde ao menos os salvos gozarão da bem-aventurança eterna. Segundo a Bíblia, haverá novos céus e nova terra, onde habitarão a justiça. Não haverá lugar para morte, nem sofrimento ou dor. Nem mesmo a possibilidade de uma nova rebelião. Em outras palavras, o segundo paraíso será melhor que o primeiro, no Éden, quando era possível e de fato houve a rebelião de Adão e Eva contra o Criador. Não haverá a possibilidade do ser humano redimido cometer roubo, adultério ou amaldiçoar a Deus. Ele não terá tal opção. Em outras palavras, ele não terá livre-arbítrio para pecar. Se houvesse a possibilidade de uma nova rebelião, o céu não seria um lugar de bênção, mas de maldição. Dessa forma, se seguirmos as consequências lógicas da doutrina cristã da vida após morte, o lugar de maior alegria e onde gozaremos de forma mais plena nossa humanidade será exatamente o lugar onde não mais teremos livre-arbítrio. "No céu nos alegraremos por um motivo: por não termos livre-arbítrio" (CLARK, 2001, p. 109). A explicação é que uma das coisas que não podemos fazer de forma alguma no céu é pecar, isto é, violar a lei de Deus. Logo, era possível Deus evitar o mal neste mundo atual privando-nos do livre-arbítrio, pois é exatamente isso que ele fará no novo céu e nova terra.

\subsection{Deus é a causa última de todas as coisas}

$\mathrm{Na}$ teologia reformada ou calvinista, Deus é visto não apenas como onipotente e onisciente, mas também como soberano. A predestinação divina decorre por necessidade lógica. $\mathrm{O}$ mundo foi criado por um Criador todopoderoso, e a história segue de acordo com o seu plano eterno. Sendo assim, Deus é o predestinador de todas coisas que vêm à existência, boas e ruins. E não se trata de mera permissão, como se Deus tolerasse que certos eventos acontecessem. Embora a utilização do termo "permissão", como uma expressão linguística conveniente, seja tolerável ao se falar sobre os decretos de Deus, Clark considerava totalmente inapropriado aplicá-lo à onipotência e soberania divina na acepção utilizada nas relações humanas (CLARK, 2001, p. 71). Por exemplo, podemos dizer que Deus permitiu que o homem pecasse, mas não se com isso queremos negar que o evento estava pré-ordenado por Deus.

Contudo, é justamente o conceito inapropriado de permissão que é geralmente usado por cristãos ao lidarem com o problema do mal. Se utilizada como solução do problema do mal, a ideia de permissão (e de livre-arbítrio) é irrelevante e ininteligível. Clark (1994, pp. 204-205) tenta demonstrar isso mediante uma ilustração: a figura de um salva-vidas numa praia perigosa. Suponhamos que um rapaz, arrastado pela forte corrente marítima, se debata sem sucesso contra as ondas, e já exausto não consiga nadar. Suponhamos ainda que o salva-vidas não faça nada. Afinal, o 
rapaz entrou no mar por contra própria. E o salva-vidas não tem nenhuma relação de causação com o mar bravio. Ele meramente "permitiu" que o rapaz se afogasse. Seria isso suficiente para isentar o salva-vidas de culpa na tragédia? Evidentemente não.

Assim, em primeiro lugar, é necessário perceber que a mera permissão para o mal não diminui a responsabilidade de alguém. O simples fato do salva-vidas não ter causado as ondas perigosas, nem arremessado o rapaz no mar, não o isentam da responsabilidade.

No caso de Deus, o apelo à permissão é ainda mais ingênuo. Afinal, ele não somente criou o rapaz, mas fez o oceano e controla todas as coisas por meio de sua providência. Logo, conclui Clark, "a ideia de permissão não faz sentido quando aplicada a Deus" (1994, p. 205). Ele ainda cita com aprovação a réplica de João Calvino àqueles que levantam objeções contra os decretos de Deus:

Alguns recorrem aqui à distinção entre vontade e permissão, dizendo que os ímpios se perdem porque Deus o permite assim, mas não porque Ele o queira. Mas como diremos que Ele o permite, se não for porque assim o quer? (CALVINO, 2009, p. 409)

Com a afirmação da soberania de Deus e da predestinação divina sobre todas as coisas, os seguidores de Agostinho, e principalmente dos teólogos da Reforma, sempre enfrentaram o problema da predestinação do mal e do pecado. Há divergência nessa área, pois não poucos chegam a negar que Deus predestine essas coisas. Estão dispostos a afirmar que Deus predestina aqueles que haverão de ser salvos, predestina os acontecimentos gerais da nossa vida, mas não os nossos pecados e falhas. Assim, dentro de sua própria tradição teológica, Clark é um dos poucos que afirma sem rodeios que Deus é a causa do mal ou do pecado:

Deve-se dizer inequivocamente que essa visão com certeza torna Deus a causa do pecado. Deus é a causa exclusiva e máxima de tudo. Não há absolutamente nada independente dele. Só ele é o ser eterno. Só ele é onipotente. Só ele é soberano. (CLARK, 1995, p. 238)

Todavia, a despeito de Deus ser considerado a causa última ou metafísica de todas as coisas, ele não é o autor do pecado ou do mal. Ao negar tal conclusão, Clark não se afasta da tradição cristã que sempre negou veementemente que Deus, sendo santo, fosse o autor do pecado. Deus não é o autor do pecado, nem faz nada que seja pecaminoso. $\mathrm{O}$ autor do pecado ou do mal é a causa imediata, a saber, o homem. Quem comete o erro é o homem, e não Deus.

Mas posto que Deus é a causa últimas de todas as coisas, Clark acredita que mesmo cristãos não calvinistas deveriam admitir que Deus é, em algum sentido, a "causa do pecado" (CLARK, 2001, p. 37). Ele é a causa última do pecado, embora não cometa o ato pecaminoso, nem o aprove ou recompense. Clark tenta esclarecer a distinção com a seguinte ilustração:

Deus é a causa de eu escrever este livro. Quem poderia negar que Deus é a causa primeira ou última, visto que foi ele quem criou a humanidade? Mas embora Deus seja a causa deste capítulo, ele não é o autor. $O$ capítulo seria muito melhor, se ele o fosse. (CLARK, 2001, p. 37)

Assim, mesmo que predestinadas, as ações das criaturas são importantes. Ao enfatizar o papel e a relevância das ações dos agentes morais, fica claro que Clark não defende o fatalismo. Alguns críticos costumam dizer, por exemplo, que se houver predestinação para a salvação ou condenação, não há qualquer sentido para as 
decisões que tomamos e as ações que executamos. Em outras palavras, perde-se o sentido de procurarmos uma vida pautada na ética e na justiça. Clark responde dizendo que tal réplica não passa de um "argumento preguiçoso", cuja falácia foi demonstrada pelos estoicos há muito tempo. A utilidade das nossas ações estaria no fato de elas serem o meio para alcançar o fim. Ou seja, a teologia reformada não defende uma ideia fatalista, onde o fim já está fixado, e os meios são irrelevantes. Antes, o fim foi predestinado para que fosse alcançado através de meios, e o valor dos meios está justamente no fato de o fim ser obtido por intermédio deles. Ou ainda: não somente o fim foi predestinado, mas também os meios para se alcançar esse fim. Como coloca o filósofo Paul Helm, "ao ordenar o fim, Deus também ordena os meios pelos quais esse fim será alcançado, e eu, como criatura dentro dessa ordem causal, tomo parte nesses meios" (HELM, 1994, p. 220). Ou, como coloca Clark, Deus "decretou que o fim será realizado por meio de meios" (CLARK, 2001, p. 38).

Por causa das doutrinas da predestinação e providência, Clark (2001) afirma que frequentemente os calvinistas precisam se absolver da acusação de fatalismo. E para refutar as acusações, é necessário perceber que há uma visão técnica e uma popular de fatalismo. A visão técnica de fatalismo seria a negação, por parte de filósofos e cientistas, de que o universo tem um propósito. Pensadores como Espinosa e Bertrand Russell negariam veementemente que os processos naturais caminham para um fim previsto. Conduto, tal visão é exatamente o oposto da doutrina bíblica da predestinação. "Deus vê o fím desde o princípio e controla todas as suas criaturas e ações de forma a garantir o resultado planejado" (CLARK, 2001, p. 62). Dessa forma, nesse sentido técnico, a Bíblia claramente não é fatalista.

Quanto à visão popular de fatalismo, esta seria aquela advogada, por exemplo, por pessoas que não entendem a dinâmica da predestinação divina, e como viver à luz desse fato. De forma resumida, constitui a visão de que, visto o fim já estar determinado, não devemos e não podemos fazer nada. Não há razão para cautela no trânsito, posto que o dia da nossa morte já está fixado. A precaução é totalmente desnecessária, pois não podemos mudar o que está determinado de antemão. Contudo, embora a Bíblia ensine que todas as coisas estão determinadas com certeza, Deus, por meio de sua providência, "arranjou os eventos de acordo com a natureza de causas secundárias" (CLARK, p. 62). O que Clark está tentando dizer é que as ações dos agentes morais são relevantes, pois Deus não decretou eventos à parte de causas para esses eventos. Não importa o evento que Deus tenha decretado, o evento acontecerá necessariamente por meio de uma causa igualmente decretada. Dessa forma, no que concerne a acidentes automobilísticos, "a cautela é a causa comum da segurança, e os acidentes são causados por imprudência" (CLARK, p. 62).

Não passa de uma caricatura, então, dizer que, caso um general esteja fadado a vencer uma batalha, e um estudante a ser reprovado num exame, não há o que fazer, pois nenhuma ação terá utilidade para alterar o resultado. Antes, se o general está de fato fadado a vencer, ele também está fadado a ganhar por meio do seu esforço. $\mathrm{O}$ esforço fará parte da predestinação tanto quanto a vitória. Logo, não existe um chamado à indolência, negligência ou ociosidade. Descrever a visão calvinista dessa forma é desonestidade intelectual; é recorrer ao expediente da caricatura, em vez da argumentação lógica. 
Outro motivo pelo qual o conceito fatalista é rejeitado é que o cristão é chamado a viver de acordo com a lei de Deus. A sua ética consiste em lutar para proceder segundo os ditames da revelação de Deus, mesmo que o fracasso nessa busca seja uma realidade dolorosa e diária. Dessa forma, ele encontrará diretrizes para como viver nesta terra de sombras nos dez mandamentos e em outras porções da Escritura Sagrada, e não nos arcanos do decreto de Deus. É irrelevante para o cristão se Deus decretou que ele sofra um acidente automobilístico, colocando um fim assim a toda a sua família. $\mathrm{O}$ seu chamado é para ser um protetor do seu próximo, em especial da sua família, e isso com certeza implica diligência e responsabilidade no trânsito. Aliás, o cristão nem poderia se preocupar com tais coisas, posto que, embora Deus tenha decretado todas as coisas que acontecerão, ele não nos revelou os detalhes da nossa vida. Isso está diretamente relacionado com a questão da responsabilidade, que iremos tratar agora.

\subsection{Responsabilidade e liberdade}

Se o futuro está determinado, se cada evento é certo, como o homem pode ser responsável pelos seus atos? Seria possível ele ser responsável por atos que não poderia deixar de executar? Ao fazer tais questionamentos, Clark se lamenta ao mesmo tempo pela ausência de d efinições sobre o que seria "responsabilidade", mesmo em obras que se preocupavam com a possibilidade da responsabilidade juntamente com a predestinação divina. Diante de tal omissão, ele sugere que o homem pode ser chamado de responsável quando for possível ele ser punido ou recompensado justamente por seus atos. Isto é, o homem deve prestar contas a alguém, no caso Deus, pois responsabilidade implica a existência de uma autoridade superior que possa punir ou recompensar. Sendo assim, chamamos o homem de responsável, pois ele pode ser justamente punido por Deus.

O homem é responsável, pois ele tem obrigação de obedecer aos mandamentos de Deus. Sua responsabilidade não tem nada a ver com os decretos (não revelados) de Deus. Assim, embora o homem não possa escolher de forma contrária ao plano de Deus, Deus estabeleceu punições para as ações que consistam em quebra dos seus mandamentos.

Alguém poderia questionar: a predestinação deixa espaço para que o homem decida contrariamente aos mandamentos divinos? A resposta, chocante para não poucos, é que a predestinação é a causa do homem muitas vezes agir contrariamente aos mandamentos divinos. Portanto, a vontade secreta de Deus (predestinação) é a causa última da vontade revelada de Deus (seus mandamentos) ser quebrada pelos seres humanos. E, novamente, a sua responsabilidade tem que ver com a vontade revelada, que é do seu conhecimento.

Ao falar sobre vontade secreta e revelada de Deus, um problema parece surgir necessariamente. Deus tem duas vontades? Aparentemente, há uma contradição em dizer que "Deus proíbe $\mathrm{x}$ " e "Deus causa x". Isto é, embora as proposições "Deus proíbe $\mathrm{x}$ " $\mathrm{e}$ "Deus causa x" não sejam contraditórias entre si, elas supostamente expressam uma contradição real ou uma desarmonia interna dentro do ser de Deus. Para Clark, haja vista as proposições não serem contraditórias entre si, a suposição que Deus não pode decretar o que seus preceitos (leis reveladas) proíbem deve ser refutada mediante exegese bíblica. Com certeza, conforme o registro bíblico, as ações dos fariseus, de Pôncio Pilatos e da multidão para conseguir crucificar Jesus foram malignas. 
Todavia, Cristo mesmo disse a Pilatos: "Respondeu Jesus: Nenhuma autoridade terias sobre mim, se de cima não te fosse dada; por isso, quem me entregou a ti maior pecado tem" (João 19.11). Segundo Clark (p. 179), o texto afirma o poder causativo de cima (divino), e ainda mais claramente que Pilatos pecou e os fariseus ainda mais.

Talvez o maior exemplo de responsabilidade em meio à predestinação seja a crucificação de Jesus Cristo. A Escritura Sagrada cristã deixa bem claro que Deus pré-ordenou ou predestinou a morte de Jesus pela mão de homens perversos. Embora Herodes, Pilatos e os judeus tenham sido participantes ativos na condenação e execução de Jesus, tudo isso é descrito na Bíblia como plano de Deus. O apóstolo Pedro diz que Jesus foi "este entregue pelo determinado desígnio e presciência de Deus". Contudo, em seguida ele declara aos judeus: "vós o matastes, crucificando-o por mãos de iníquos" (Atos 22.22-23). Mais adiante, o mesmo livro de Atos registra uma oração coletiva dos cristãos do primeiro século. Em oração, eles dizem a Deus que o ajuntamento de Herodes, Pilatos e a gente de Israel para matar Jesus foi para "fazerem tudo o que a tua mão e o teu propósito predeterminaram" (Atos 4.28). Nestes trechos bíblicos, a responsabilidade dos assassinos de Cristo é afirmada, ao mesmo tempo em que se reconhece a história (incluindo os atos dos homens) como escrita de antemão por Deus.

Fazendo uso de alguns textos bíblicos, Clark também tenta ancorar a responsabilidade em outro fundamento. A pessoa que vincula a responsabilidade à liberdade da vontade, além de incorrer numa falácia, demonstra ignorância do que diz a Escritura, afirma Clark (2001, p. 111). A falácia estaria no fato de não haver nenhum vínculo lógico entre liberdade e responsabilidade. Não existe um silogismo sólido, no qual premissas verdadeiras conduzam à conclusão segura de que "reponsabilidade pressupõe liberdade". É simplesmente uma pressuposição, assumida sem prova, quer por filósofos, quer por teólogos. Quanto aos textos bíblicos, o Evangelho de João (15.22) e de Lucas $(12.47,48)$, bem como o livro do profeta Daniel (5.22), além de outras passagens bíblicas, afirmam que a base da responsabilidade é o conhecimento. Dessa forma, como todo homem conhece ao menos em parte a lei de Deus, devido ao sensus divinitatis [senso do divino], ${ }^{6}$ todo homem é responsável. Devido ao sensus divinitatis, ${ }^{7}$ todo ser humano vem ao mundo com certo conhecimento de Deus, do que é certo e errado. Ele possui a lei gravada em seu coração, como diz o apóstolo Paulo em Romanos, capítulo 1. Tal conhecimento é a base da sua responsabilidade perante Deus.

Diante dessa resposta, alguém pode mudar ligeiramente a pergunta. Em vez de questionar a possibilidade da responsabilidade humana diante da predestinação divina, um crítico pode colocar em xeque a justiça divina. Como pode Deus ser justo em tal conjuntura? É sobre isso que discorremos agora.

\footnotetext{
${ }^{6}$ Sensus divinitatis é a ideia de que Deus criou o ser humano com uma faculdade cognitiva que produz crença em Deus sem evidência ou argumento

7 O conceito de sensus divinitatis foi bem desenvolvido por João Calvino (1509-1564), o reformador francês. Atualmente o filósofo Alvin Plantinga tem usado este conceito, conforme elaborado por Calvino, na construção de sua defesa do teísmo cristão. Vide Conhecimento e crença cristã (Brasília: Academia Monergista, 2016).
} 


\subsection{Deus é justo por definição}

O debate acerca do problema do mal invariavelmente levará a uma discussão sobre a justiça de Deus. Mas o que é justiça? Ao buscar uma definição, Clark menciona a famosa posição de Leibniz (Discurso de metafísica) de que o nosso mundo é o melhor de todos os mundos possíveis. O motivo é que Deus poderia ter escolhido qualquer um dos mundos possíveis, mas acontece que ele escolheu o melhor. Esse mundo é o melhor não porque Deus o escolheu, mas Deus o escolheu porque era o melhor mundo disponível.

A rejeição da versão adotada por Leibniz é notória quando Clark lida com o conceito de justiça. Deus é soberano e por isso faz tudo o que deseja. E tudo o que Deus faz é justo simplesmente por ele ter feito. Dessa forma, segue o argumento, se Deus pune um homem, tal homem está sendo punido justamente e, dessa forma, é responsável. Ou, para usar o exemplo de Leibniz, se Deus escolheu atualizar este mundo, este é o melhor de todos os mundos. Aos nossos olhos, isto é, segundo os nossos padrões, Deus poderia ter atualizado um mundo melhor. Por exemplo, ele poderia ter criado um mundo sem a existência de mal ou sofrimento. Este mundo era possível, posto que Deus é soberano e onipotente. Logo, este mundo é o melhor, pois foi o mundo que Deus escolheu atualizar, e não porque ele não tinha outro melhor possível de ser atualizado. Aliás, segundo a crença cristã da ressurreição dos mortos e da restauração de todas as coisas, Deus de fato atualizará um mundo melhor no futuro. Ele apenas não escolheu atualizá-lo no princípio de todas as coisas.

Para Clark, nós conseguimos determinar o que é a justiça observando o que Deus faz de fato.
Tudo o que Deus faz é justo, pois Deus é justo por definição. Eis parte do seu arrazoado:

Deus não é responsável nem pecaminoso,
embora seja a única causa suprema de tudo.
Ele não é pecaminoso porque, em primeiro
lugar, tudo quanto Deus faz é justo e reto. É
justo e reto simplesmente em virtude do fato
de ser ele quem faz. Justiça ou retidão não é
um padrão externo a Deus, ao qual ele está
obrigado a se submeter. Retidão é aquilo que
Deus faz. (CLARK, 1995, p. 240)

Ao afirmarmos que Deus é justo ou injusto, estaremos necessariamente, mesmo que de forma inconsciente, assumindo um padrão ético. Contudo, se Deus existe, ele é o seu próprio padrão de conduta. Ninguém pode assumir um padrão de certo ou errado externo a Deus, e mediante esse padrão autônomo julgar os seus atos e decisões. Se Deus é Deus, o homem não pode colocá-lo no banco de réus.

Assim, se Deus decide considerar toda a humanidade responsável pela culpa do primeiro ser humano, ele é justo ao fazê-lo. E se, de forma similar, ele considera apropriado contar como justos todos aqueles por quem Cristo morreu, ninguém pode questionar os seus caminhos. Ele é justo ao utilizar o princípio da representatividade em ambos os casos, simplesmente por ser Deus e ser dono das obras de suas mãos. Tal visão sempre foi inaceitável e até ofensiva a muitas pessoas, inclusive cristãs. Esse repúdio levou Lutero certa feita a exclamar: "Deixem Deus ser Deus" (WATSON, 2000).

Como diz Clark (2001, p. 187) em outro lugar, o certo é o que Deus ordena. Errado é o que ele proíbe. Não existe outra base para distinções morais.

Contudo, mesmo que assumamos a lei de Deus como padrão ético e moral, isso não parece resolver a questão. Ou melhor, parece levantar outro problema. Em sua lei, Deus claramente 
proíbe que assassinemos o nosso próximo. No famoso Sermão da Montanha, Jesus explica o princípio por detrás desse mandamento, declarando que mesmo o ódio no coração, não externado em ações, é absolutamente condenado por Deus. Contudo, de acordo com o conceito calvinista de predestinação, todos os eventos foram pré-determinados por Deus. Não devemos furtar, mas em última instância todos os furtos ocorridos na humanidade foram parte do plano de Deus. Com certeza, não podemos assassinar, mas todos os assassinados que foram concretizados não passaram do cumprimento daquilo que Deus havia escrito antes da fundação do mundo.

De fato, não podemos julgar a Deus de acordo com os nossos próprios padrões éticos e morais. Afinal, ele é Deus. Contudo, Deus ainda parece injusto quando analisamos os seus atos à luz da sua própria lei, particularmente os dez mandamentos. Isso nos leva a outro ponto: se Deus está obrigado ou não a obedecer a sua lei.

\subsection{Deus é Ex-lex}

Ao lidar com a questão da justiça de Deus, alguém poderia sugerir que Deus pecou, ou ao menos errou, por exemplo, por ter predestinado que Judas Iscariotes traísse Jesus. Afinal, pelo menos em última instância, o motivo de Judas ter violado de maneira tão trágica a lei de Deus, foi a predestinação divina. Deus escolheu que Judas traísse o seu Filho e o entregasse nas mãos de líderes assassinos. Em Atos dos Apóstolos, capítulo 1, versículo 16, o apóstolo Pedro afirma que "convinha que se cumprisse a Escritura que o Espírito Santo proferiu... acerca de Judas". Ou seja, Deus não apenas havia predestinado o acontecimento, mas também anunciado há séculos por meio dos profetas.
As premissas da objeção estão de acordo com a teologia calvinista. De fato, Judas violou a lei divina por causa da predestinação do próprio Deus. Contudo, Clark afirma (1995, p.240) que “por definição Deus não pode pecar". Além do mais, predestinar o pecado não é pecar. A Bíblia define pecado como qualquer falta de conformidade ou transgressão da lei de Deus. Mas na lei de Deus não existe nenhuma proibição sobre Deus predestinar atos pecaminosos.

Além disso, embora a definição de pecado apresentada pela Bíblia seja de suma importância para a raça humana, isso não se aplica ao próprio Deus. Pecado é transgredir a lei de Deus, e os homens são julgados por essa mesma lei ao transgredirem. Contudo, Deus não é como o homem. Ele é Criador, e não criatura. Ele não pode ser julgado pela lei, pois está acima dela. Como diria Clark (1995, 240), Deus é "Ex-lex".

Deus está acima da lei, pois as leis que ele impõe sobre os homens não se aplicam à sua natureza divina. Segundo Clark (1995, p. 241), elas se aplicam somente às condições humanas. Um exemplo disso é o roubo. É impossível que Deus roube, pois, além de tudo o que ele faz ser justo por definição, ao Senhor pertence a terra e tudo o que nela se contém. Não existe alguém de quem ele possa roubar algo. Tudo é dele. O oitavo mandamento, "Não furtarás!", é simplesmente inaplicável a Deus.

Outro exemplo claro é o assassinato. Embora a Bíblia proíba severamente o assassinato, afirmando que é digno de pena de morte quem o fizer, é impossível que Deus cometa tal pecado. Ele é o Senhor de todas as coisas, e pode tirar a vida de quem lhe aprouver. $\mathrm{O}$ exemplo de Abraão e Isaque demonstra claramente a impossibilidade de julgar a Deus pela lei divina entregue aos homens. Seria uma 
abominação um ser humano pedir a um pai que sacrificasse o próprio filho, mas foi exatamente o que Deus fez a Abraão. Mesmo não tendo permitido que o sacrifício se concretizasse, em nenhuma porção da história o pedido de Deus é retratado como impróprio, muito menos pecaminoso. Dessa forma, mesmo o quinto mandamento, "Não matarás!", não pode ser aplicado a Deus. Ele pode tirar a vida de qualquer uma de suas criaturas, até mesmo do seu próprio Filho, e de uma forma cruel.

Outra forma de vermos a inaplicabilidade do quinto mandamento a Deus é a seguinte: assassinato na Bíblia é tirar a vida de outro ser humano sem sanção divina. ${ }^{8}$ É por isso que Abraão nunca poderia ter sido acusado de assassinato, mesmo que Deus não o detivesse no monte Moriá. ${ }^{9}$ Além disso, assassinato é algo que só pode ser realizado por outro ser humano, ou pelo menos por um ser racional. Assim, animais nunca praticam assassinato no mesmo sentido que seres racionais. Considerando essa definição de assassinato, e considerando que Deus é um ser racional, ele só poderia praticar assassinato se tirasse a vida de alguém sem a sua própria permissão. Posto que Deus não é esquizofrênico, essa é uma alternativa absurda e impossível. Logo, como já notamos anteriormente, permanece o que Clark (1995, p. 241) disse: as leis que a Bíblia prescreve se aplicam somente às condições humanas. Elas não se aplicam a Deus. Deus está "fora da lei". Ele é "Ex-lex".

Interessantemente, quando o apóstolo Paulo, na carta aos Romanos, capítulo 9, discorre sobre a predestinação divina, ele recorre a um expediente semelhante. Após propor diversas objeções que poderiam ser levantadas contra a doutrina que ora ensinava, Paulo pergunta:
"Quem és tu, ó homem, para discutires com Deus?!" (9.20). Não podemos discutir com Deus, pois não podemos julgá-lo. Ele é lei para si mesmo e para todos. Ninguém pode julgá-lo, mesmo utilizando a sua lei.

\section{CONSIDERAÇÕES FINAIS}

A solução proposta por Gordon Clark ao problema do mal não ficou imune a objeções. Críticos apontaram dificuldades encontradas na argumentação, bem como implicações supostamente perigosas ao teísmo cristão. Talvez o maior desafio à posição de Clark seja a de que ela torna Deus o "autor do pecado", um tirano cósmico. Clark respondeu dizendo que Deus seria o "autor do pecado" apenas no sentido de que ele é o responsável por todas as coisas em seu universo, desde as mais irrisórias, como a queda de uma folha, até as mais portentosas, seja uma catástrofe natural ou a decisão de um ditador de exterminar milhares de pessoas. Contudo, a expressão seria inapropriada, pois Deus não é o "autor do pecado" na acepção mais comum do termo. Ou seja, ele não é o agente imediato de tais ações. A lei da gravidade é "responsável" pela queda da folha, as catástrofes naturais possuem causas materiais para a sua ocorrência e o ditador dá a ordem para que seus súditos exterminem homens, mulheres e crianças.

Tal explicação, que tenta colocar a responsabilidade pelo ato no autor imediato da ação, também enfrentou grande oposição. Afinal, o ditador mencionado em nosso exemplo dificilmente seria eximido de culpa por não ter puxado o gatilho nas execuções em massa. Ele poderia não ser o autor do crime em

\footnotetext{
${ }^{8}$ Considerando o original hebraico, o mandamento é na verdade "não assassinarás".

${ }^{9} \mathrm{O}$ evento está descrito no capítulo 22 do livro de Gênesis.
} 
certo sentido, mas seria igualmente ou até mesmo mais responsável do que os agentes secundários do genocídio. A resposta de Clark seria a distinção entre Criador e criatura. Deus não pode ser julgado pelo homem, nem pode ser posto num tribunal. O que ele faz é justo por definição, mesmo que não o seja para o homem. Isto é, ele pode matar e permanecer justo, enquanto ao homem é proibido tal direito.

A despeito das críticas, não é possível subestimar a importância da filosofia de Gordon Clark, principalmente para os cristãos dos seus dias. Numa época em que o cristianismo foi acusado vigorosa e crescentemente de irracionalismo, em parte devido aos avanços da cosmovisão evolucionista na academia e na sociedade, os escritos de Clark serviram de grande encorajamento àqueles que tentavam justificar as suas crenças.

Para Clark, os cristãos não deveriam temer o debate público, nem mesmo o estreitamente acadêmico, pois crer não significa abrir mão da razão e da racionalidade. Diferente de uma interpretação popular (e equivocada) de Kierkegaard, ${ }^{10}$ a "fé não é um salto no escuro". A fé não pode ser dissociada da razão, pois Deus mesmo é o autor de ambas.

Assim, a produção literária de Clark desempenhou importância particular no desenvolvimento da apologética cristã no século XX. E, nesse aspecto, de particular importância foi sua conciliação do problema do mal com a bondade e onipotência de Deus, tema que sempre dominou as discussões acerca da existência de Deus, quer na academia, quer na rua.

Subindo nos ombros de gigantes teológicos como Santo Agostinho e João Calvino, Clark apresenta um Deus que não é vítima das suas próprias criaturas, mas sim Senhor delas, inclusive de suas decisões.

A sua proposta deve ser considerada ao lado daquelas de Richard Swinburne e Marilyn Adams, posto que Clark, a semelhança destes, lança mãos da teologia e de pressupostos teológicos para lidar com o problema do mal. Para eles, o recurso à teologia cristã é uma forma de lidar satisfatoriamente com o problema do mal.

A proposta de Gordon Clark parece-nos coerente com o teísmo cristão, e evita o apelo ao mistério ${ }^{11}$ e às contradições, tão presentes na maioria das teodiceias. A atitude de Bahnsen (1996), um distinto filósofo e apologista cristão, é bem característica do que encontramos na maioria das obras acerca do assunto. Após demonstrar em várias páginas que o problema do mal não invalida o cristianismo, bem como responder algumas das objeções mais comuns, Bahnsen termina o seu texto afirmando que o assunto permanece um mistério para todos nós. A proposta de Clark pelo menos evita esse tipo de apelo ao mistério.

Por outro lado, talvez seja interessante ver o alcance da resposta clarkiana para o problema

\footnotetext{
${ }^{10}$ Para mais sobre o assunto, veja M. Jamie Ferreira "Faith and the Kierkegaard leap", In: The Cambridge Companion to Kierkegaard (Cambridge: Cambridge University Press, 1998).

${ }^{11}$ Mistério, na teologia cristã reformada, significa uma verdade que não estava revelada, e foi posteriormente manifesta por Deus. Em Colossenses 1.25, o apóstolo Paulo fala sobre "o mistério que estivera oculto dos séculos e das gerações; agora, todavia, se manifestou aos seus santos" (ênfase adicionada). Muitos, contudo, utilizam o termo "mistério" para designar algo impossível de ser explicado ou mesmo entendido. Para Clark, e outros teólogos da tradição reformada, mistério nessa acepção não faz parte das doutrinas nas quais devemos crer.
} 
existencial do mal, tão pouco desenvolvido pelos filósofos. Embora em certo sentido a proposta de Clark possa servir de alento para cristãos que sofrem neste mundo, pois tomam conhecimento de que Deus está no controle de todas as coisas, inclusive dos sofrimentos particulares de cada ser humano, o aspecto pastoral dessa proposta pode e deve ser avaliado com maior atenção. ${ }^{12}$ Uma mãe de quem nasceu um filho deficiente pode receber consolo no fato que Deus quis deliberadamente que isso acontecesse assim? Uma idosa que toma conhecimento que o seu genro, possuído dos efeitos entorpecentes de bebida alcoólica, tirou a vida de sua filha e netos de forma violenta, encontrará paz e alento na afirmativa que Deus predestinou que isso aconteceria exatamente assim?

Certamente não podemos analisar a veracidade de uma doutrina com base nos efeitos psicológicos produzidos nas pessoas. Contudo, dada a complexidade do assunto da coexistência de Deus e do mal, sempre será necessário estudo e pesquisa adicionais. Lembrando novamente o professor Sérgio Miranda (2013, posição 37), estamos tratando de um problema filosófico autêntico, isto é, um problema que nunca receberá uma resposta definitiva. Assim, seria de muito proveito analisar a eficácia da solução de Gordon Clark ao problema do mal no enfrentamento das questões existenciais daqueles que sofrem tragédias e são objeto dos males que Deus predestinou que ocorram neste mundo.

\section{Referências bibliográficas}

BAHNSEN, Greg L. Always Ready. Texarkana, AR: Covenant Media Foundation, 1996.

Bíblia Sagrada. Tradução João Ferreira de Almeida. Edição Revista Atualizada, 1993. Sociedade Bíblica do Brasil.

CALVINO, João. A instituição da religião cristã, Tomo II, Livros III e IV. São Paulo: Editora UNESP, 2009.

CLARK, Gordon H. Clark and His Critics. Phillipsburg, NJ: Presbyterian and Reformed Publishing Company, 2009.

CLARK, Gordon H. Essays on Ethics and Politics. Jefferson: The Trinity Foundation, 1992.

CLARK, Gordon H. God's Hammer: The Bible and Its Critics. Jefferson: The Trinity Foundation, 2011.

CLARK, Gordon H. Religion, Reason and Revelation. Jefferson: The Trinity Foundation, 1995.

CRAMPTON, W. Gary. The Scripturalism of Gordon H. Clark. Jefferson: The Trinity Foundation, 1999.

FRAME, John. Apologetics to the Glory of God: An Introduction. Phillipsburg, NJ: Presbyterian and Reformed, 1994.

HELM, Paul. The Providence of God. Leicester: Inter-Varsity Press, 1994.

HUME, David. Diálogos sobre a religião natural. São Paulo: Martins Fontes, 1992.

\footnotetext{
${ }^{12}$ Deve se questionar não somente se a teodiceia clarkiana possui o potencial para essa aplicação pastoral, mas também a relevância filosófica desse aspecto.
} 
INWAGEN, Peter van. Christian Faith and the Problem of Evil. Grand Rapids: Eerdmans, 2004.

MIRANDA, Sérgio, ed. O problema do mal: Uma antologia de textos filosóficos. São Paulo: Poiesis Editora, 2013. Edição Kindle.

NASH, Ronald H. Gordon H. Clark. In: ELWELL, Walter A. Evangelical Dictionary of Theology. Baker, 1996.

PIPER, John. Amazing Grace in the Life of William Wilberforce. Illinois: Crossway Books, 2006.

WATSON, Philip S. Let God be God! An Interpretation of the Theology of Martin Luther. Eugene: Wipf and Stock, 2000.
PEREBOOM, Derk. "The Problem of Evil". In: The Blackwell Guide to the Philosophy of Religion. Oxford: Blackwell Publishing, 2005.

SWINBURNE, Richard. Providence and the Problem of Evil, Oxford University Press, 1998.

SWINBURNE, Richard. The Existence of God, 2d ed., Oxford University Press, 2004. 